SNEŽANA GOLUBOVIĆ, Institute of Archaeology

Belgrade, Serbia

arheosneska@gmail.com

NEMANJA MRĐIĆ, Institute of Archaeology

Belgrade, Serbia

nemanjamrdjic@gmail.com
904:725.182]:004.92"652"(497.11)

930.85(497.11:100)

COBISS.SR-ID 264134156

Original research article

Received: April 06 2018

Accepted: April 30 2018

\title{
REBIRTH OF THE PAST - RECREATING VIMINACIUM IN 3D AND PRESENTING ROMAN CULTURAL HERITAGE
}

\begin{abstract}
Recreating invisible or highly damaged archaeological remains in 3D technologies has become one of the best ways to bring the past to regular visitors. The Project ARCHEST was designed to improve the presentation of the site and to, consequently, attract new visitors. The main objectives were supporting the archaeology-related creative sectors to operate transnationally and to increase the knowledge of common Roman history through the most important archaeological sites. Additionally, there was an objective to increase the audience with an integrated approach and modern technology, transforming a non-audience into a new audience and changing the opinion that archaeology is something boring or too elitist. The results of the project have a huge appeal to ordinary audiences and support a better understanding and acceptance of Roman civilization through clear images which, at the same time, do not contradict the scientific concept but, rather, aim to support it.
\end{abstract}

\section{KEYWORDS: 3D RECONSTRUCTION, VIRTUAL REALITY, VIMINACIUM, ARCHEST.}

\section{INTRODUCTION}

A visualisation of the past is one of the most important results of archaeology ${ }^{1}$. To make something invisible visible could be viewed as one of the most important scientific "commandments". Archaeologist study and explore ancient remains thoroughly and systematically to understand and interpret sites and events that disappeared millennia ago. However, people who visit sites and

1 The article is the result of the projects: Viminacium, Roman city and military camp - research of material and non- material culture of inhabitants by using the modern technologies of remote detection, geophysics, GIS, digitalization and $3 D$ visualization (no 47018), funded by The Ministry of Education, Science and Technological Development of the Republic of Serbia. Project ARCHEST was co-financed by the European Union through the Creative Europe (2014-2020) Culture Sub-Programme Support for European Projects. museums are not scientists and are not able to understand remains in the same way as professionals. Rubble or rubbish for one is a valuable source of information for others and bridging the divide between science and tourism, or archaeologists and visitors, emerges as a serious problem. The imagination of visitors is often influenced by Hollywood or their own fairytale dreams that are not based on long term studies typical of professional.

This project was aimed at improving the presentation of the site and to attract new visitors using modern technologies that are still being developed in the presentation of the cultural heritage.

Therefore, in order to recreate a city destroyed 16 centuries ago we must use both. A professional approach with decades of excavations and research combined with elements of scientific 
imagination should lead to a result that is more understandable for visitors.

\section{METHODS AND RESULTS}

Viminacium was among the first projects to involve Geophysical Surveys in their research process. Since 2002, systematic surveys of the legionary fortress, city and suburban zones have been systematically surveyed using multiple methods to get as clear an image as is possible of all areas. GPR (Ground Penetrating Radar), proton magnetometer, electro resistivity are the most commonly used methods of survey of Viminacium's territory. Arial and satellite imagery were introduced at the same time, together with the development of the GIS and archaeological databases. The total area covered by the multidisciplinary surveys exceeds 600 hectares, of which 150 hectares were thoroughly scanned in high detail by different survey methods.

This was the solid foundation for the creation of the large scale model that combined the results

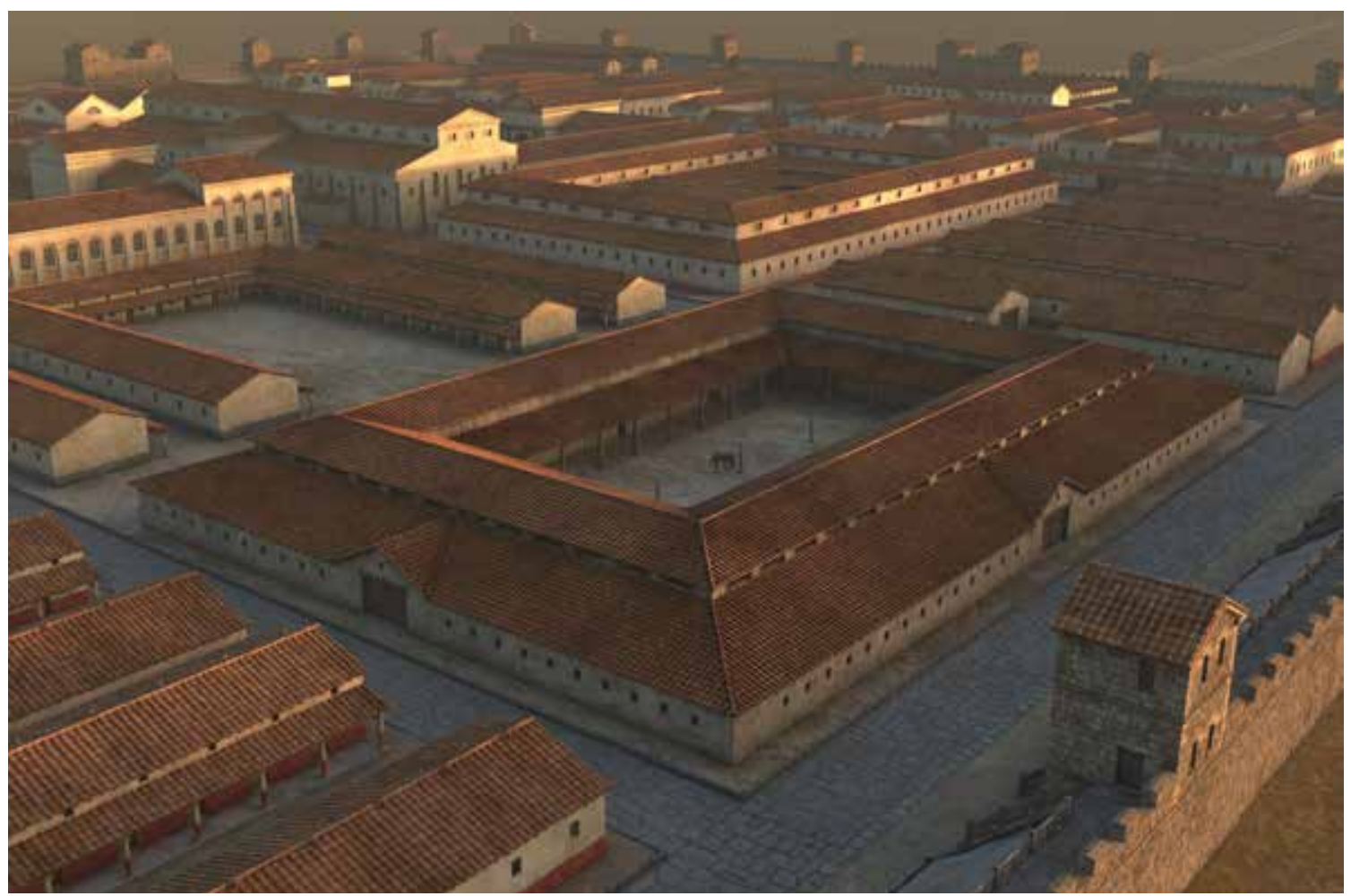

Fig. 1 Viminacium castrum reconstructed in 3D of the long term surveys of the city and fortress and, unfortunately only partial, excavations. Since the remains of Viminacium are not visible on the surface any more this was important for the development of tourism and the future Archaeological mains and their presentation to the public became the spearhead project that finally resulted in the quicker development of the site.

The dimensions of the scale model are $3.5 \mathrm{x}$ $7.5 \mathrm{~m}$ and, with the use of light materials (card board and plywood), its creation enabled us to make it the focal point of a small mobile exhibition that is part of a both permanent and more than twenty temporary exhibitions that were presented in Europe and North and South America.

During excavations, all buildings are documented via high quality 3D modelling. These are achieved using 3D laser scanning, photogrammetry and aerial drone imaging. All these methods were combined where it was possible to do so. Park. The visualisation of the archaeological re- 


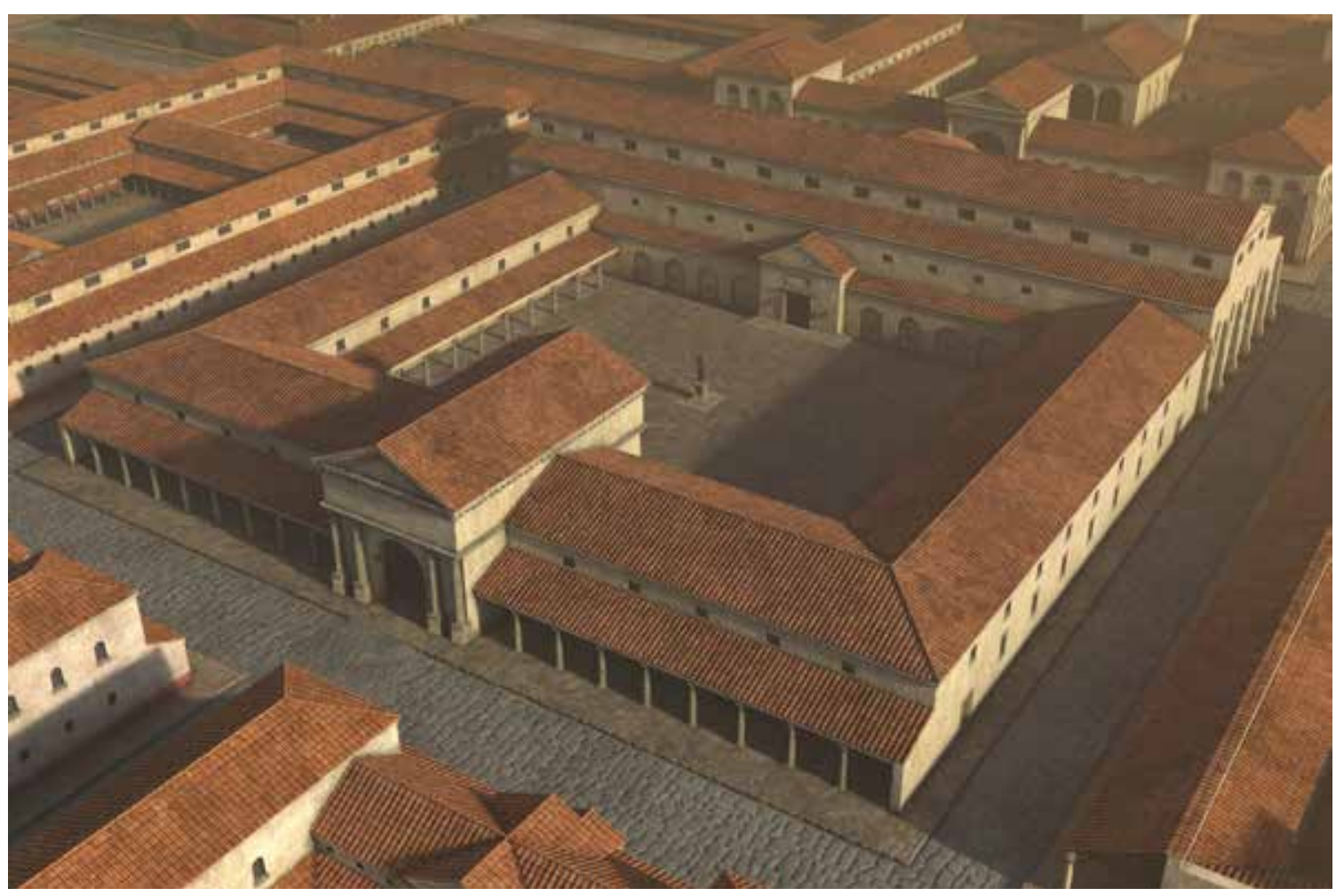

Fig. 2 Viminacium castrum reconstructed in 3D, principia.

During creation of the $3 \mathrm{D}$ model $^{2}$, special attention was paid to accuracy and details in order to ensure a high level of realism. The technique used is the so-called "polygonal modelling", a technology that allows you to get closer to the true model and avoid the effects produced by the rendering where the edges do not "live" and where realism is guaranteed by the textures used with the limits provided by their two-dimensional nature. All materials were created from measurements of the visible architectural remains available or 3D laser scans in order to achieve maximum realism. Other sources were also used: any existing 3D models, floor plans, elevations related to the excavation areas, indications from scientific referees, graphic reconstructions related to other similar buildings. Analogies of known structures are widely used during scientific research and model creation.

The technique of lighting adopted is image-based lighting (HDRI), an innovative tech-

2 3D model je izradila kinematografska i televizijska produkcija DEDALUS ER, Beograd. Zoran Marković PR nology that allows designers to recreate, in a very realistic way, the light shown in photos taken at the related site. The technology is the same as that used in movie productions. The software used was Autodesk 3D Studio MAX. Thanks to this solution, it was possible to give not only realism but also emotional content to the audience. This was achieved with the use of different weather conditions and with adaptations of the presented architectural type (sunset, sunrise, night, storm, etc.).

A hi-poly 3D model of all the elements was reconstructed and, naturally, this formed the backbone of the project. The model had the same processing level used for the final production of the static images, of the animation and the future 3D virtual environment.

On the basis of the model, static renderings of virtual reconstructions were exported. The rendering, generated on the basis of a mathematical model of the 3D scene, was delivered as raster images in high resolution both in JPG and TIFF formats (Figures 1-9). 


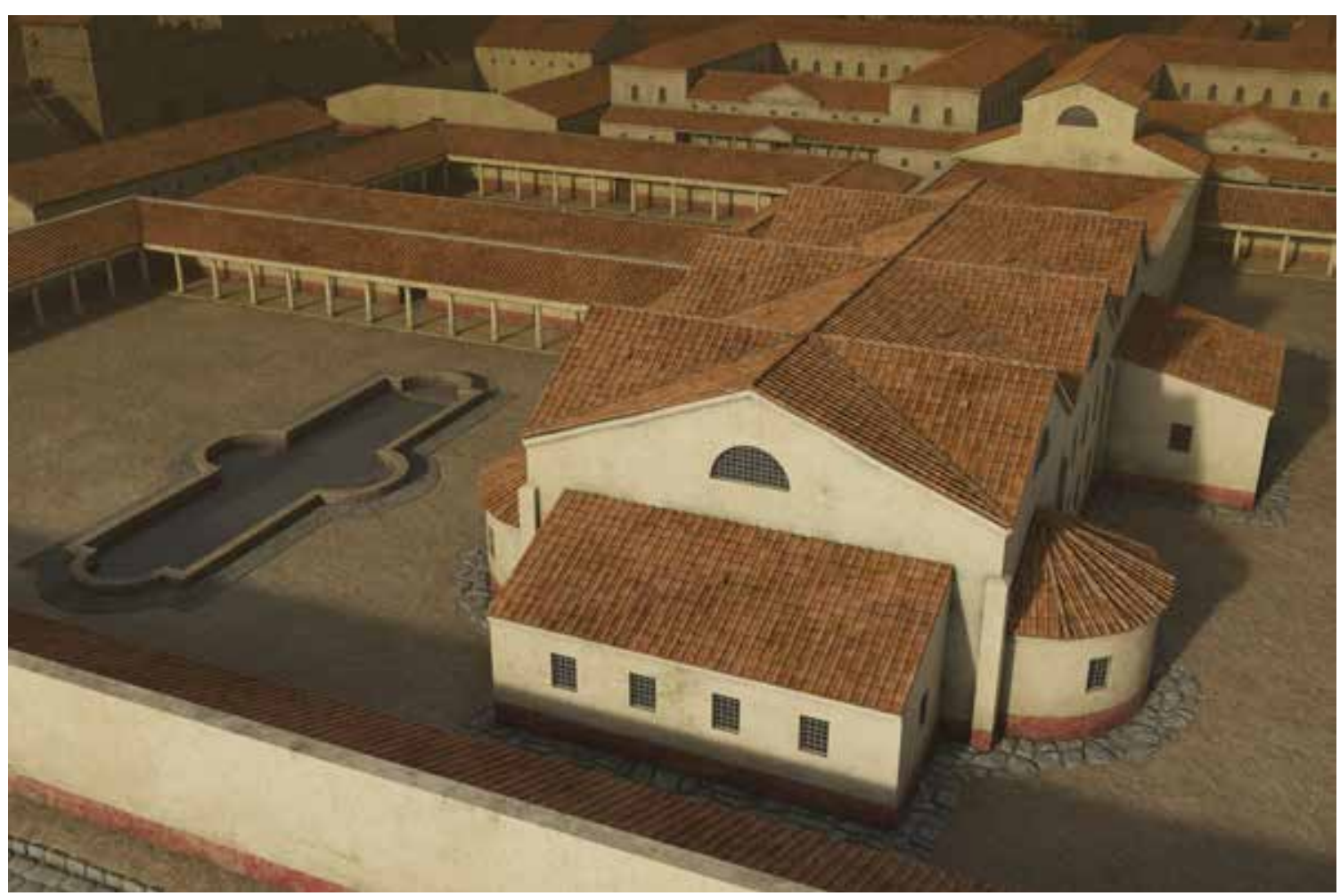

Fig. 3 Viminacium castrum reconstructed in 3D, military baths (thermae)

On the basis of model that was produced, a 3D animation walk through video was created. The video represents a short virtual tour of the reconstructed environment through one or more 3D camera(s). This video is in FULL HD resolution and is available on the project web sites ${ }^{3}$.

All 3D materials can be uploaded from the website to a tablet. The first version helps to familiarise the user with the remains that can be visited in the Archaeological Park, while the second version that is uploaded to a tablet can be used during guided tours and educational workshops.

\section{FUTURE VISION OF PRESENTATION AND USE OF THE DIGITAL MODEL}

There is a plan to create a real-time $3 \mathrm{D}$ optimised version together with Real Time software

3 Viminacium castrum 3D video available at https://vimeo.com/user73152746

Viminacium amphitheatre 3D video available at https:// vimeo.com/239510667 for exploration, which will allow free virtual navigation in both external and internal digitally created environments.

The level of detail of the digital models for 3D navigation will be well balanced in order to ensure an optimal level of visual rendering as well as a smooth flowing interaction.

\section{PROJECT ARCHEST - THE ROAD TO VISUALISING THE PAST IN 3D}

The ARCHEST Project - the education of visitors to archaeological sites along the Roman road Aquileia-Emona-Sirmium-Viminacium - is a continuation of the T-PAS project, co-financed by the CULTURE PROGRAM 2007-2013, which brought together institutions from Italy, Slovenia and Serbia. Besides the Aquileia Foundation (Fondazione Aquileia), the leading partner, museum and galleries of the City of Ljubljana, the Institute for the Protection of Cultural Monuments, Sremska Mitrovica and the Institute of Archaeolo- 


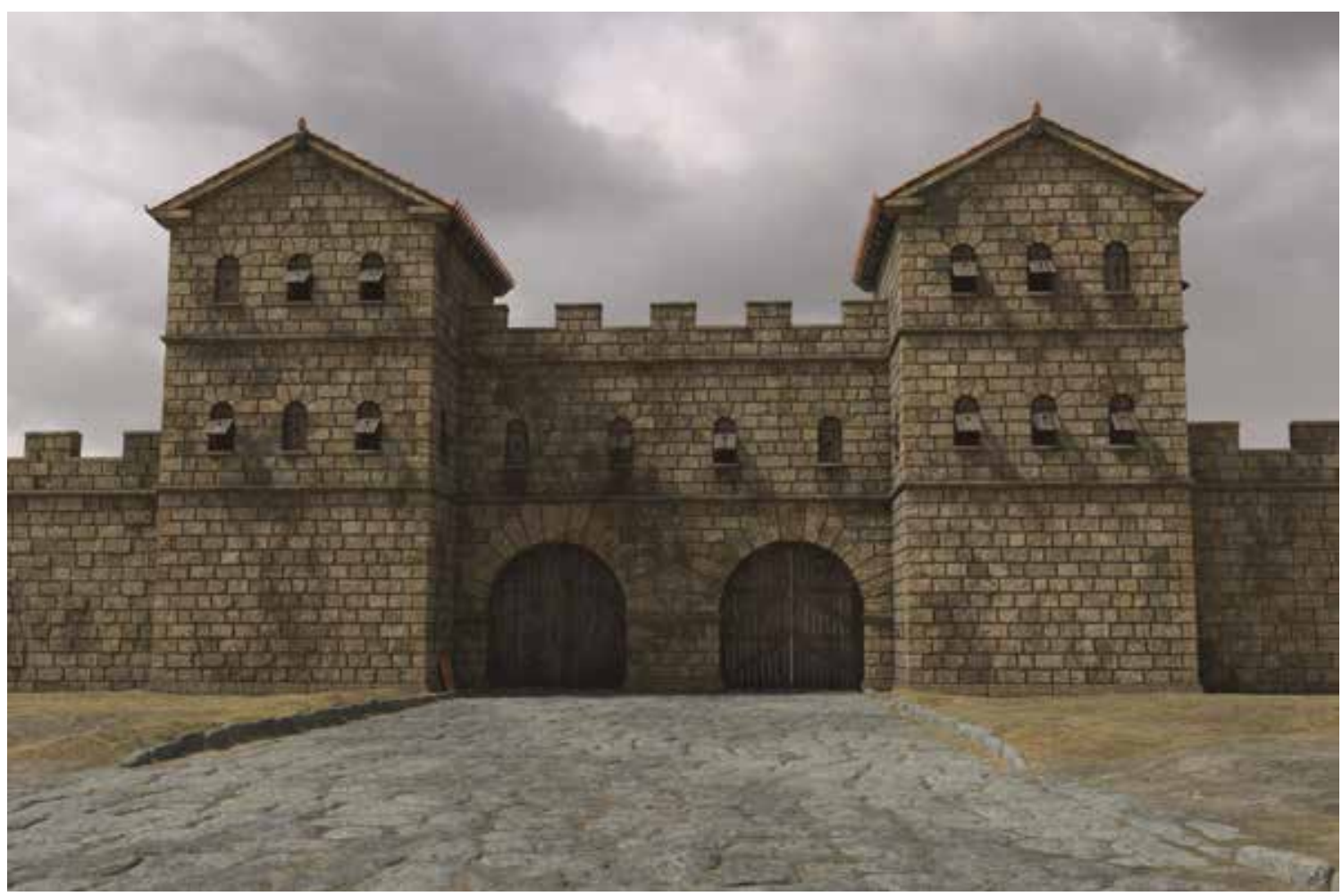

Fig. 4 Viminacium castrum reconstructed in 3D, porta praetoria, front view.

gy in Belgrade were included in the project.

The ARCHEST project was co-financed by the European Union through the Creative Europe (2014-2020) Culture Sub-Programme Support for European Projects. As with the previous project, this one was also coordinated by the Fondazione Aquileia. It was expected to last 24 months, starting on $1^{\text {st }}$ September 2015 and concluding on $31^{\text {st }}$ August 2017. However, since it actually started in January, the project was prolonged until $31^{\text {st }}$ December 2017.

The new project relied on the results of the earlier one with which were realised: research on the Roman route connecting sites that are taking part in the project, a socio-economic analysis, tourist promotion of the route in schools, didactic laboratories for primary schools, a photo contest for younger pupils and three conferences at each site organised together with a touring exhibition on the route. This inheritance provided the impetus for identifying activities to be implemented in the new project with the vision to extend the cooperation in the future with other sites of the same char- acter in Romania, Greece, Bulgaria and Turkey.

Even the title of the project, ARCHEST, with the meaning Archaeology Est, as a mixture of a contemporary English word and the Latin word that means "it is", expresses the tendency to emphasise the application of modern technologies in the reconstruction of the past.

Included in the project T-PAS were three ancient cities: Aquileia, Emona and Viminacium, 4 and in ARCHEST a fourth city joined them Sirmium, today's Sremska Mitrovica. The joining was inevitable considering Sirmium was the administrative centre of the province of Pannonia Inferior, later Pannonia Secunda and, during the period of the Tetrarchy, one of four tetrarchic capitals. Ancient writers describe it as one of the six most beautiful and richest cities in Illyricum. Founded in the territory of the Sirmian and Amantin tribes, it very quickly acquired the status of a

4 The development and the importance of these cities were described in N. Mrđić, S. Golubović, T-PAS - Project on tourist promotion of the archaeological sites along the route Aquileia, Emona, Viminacium. Arheologija i prirodne nauke 8 (2012), Beograd 2013, 101-112. 


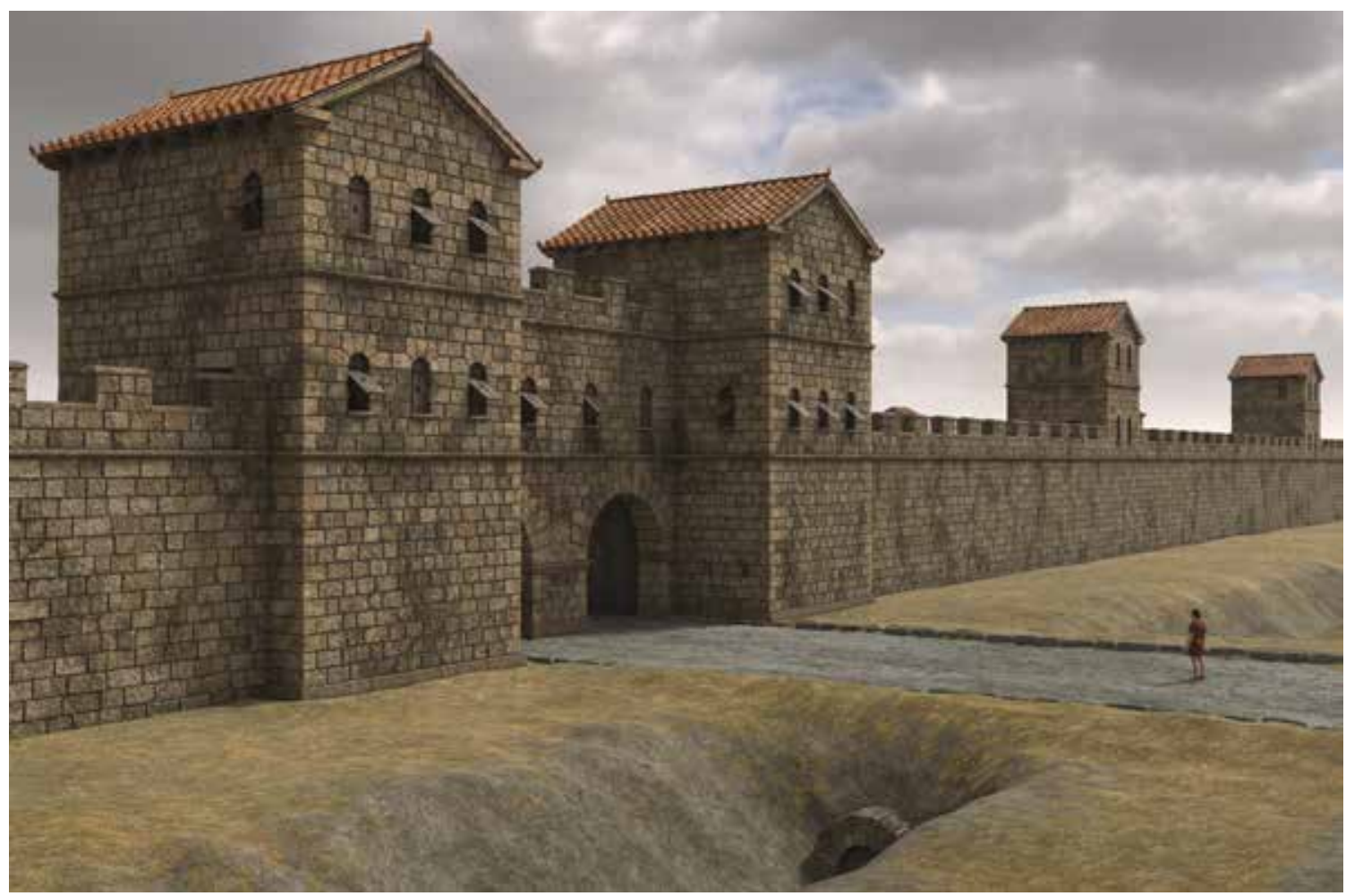

Fig. 5 Viminacium castrum reconstructed in 3D, porta praetoria, side view.

colony, probably during the reign of Domitian and became Colonia Flavia Sirmium. The city developed and flourished in the period from the 1 st to the 6th century $\mathrm{AD}$, thanks to, among other things, the efficient road network. The most important road was the one connecting these four cities. Sirmium was known as an important Christian centre and by its many martyrs who suffered for their religious beliefs (Popović 1993; Tiussi, C., 2013: 65). Representatives of this fourth site were introduced at the first meeting in Aquileia and quickly integrated into the existing team so that the partnership cooperation flowed smoothly and to the general satisfaction of all concerned.

The main objective of the project was the presentation of four exceptionally important archaeological sites from the Roman period through the creation of $3 \mathrm{D}$ reconstructions and the introduction of augmented reality technology which would bring visitors closer to the look of the settlement in ancient times. In other words, real-world information is combined with computer content and displayed on a computer, tablet, or mobile phone screen. The four sites are characterised by a lack of easily understandable remains. They are not like Pompei or Rome where is easier to understand how a Roman town, temple or theatre was built. So, in order to increase and develop the audience and to attract new visitors, an essential task was to work on 3D reconstructions because this was the only way to let people understand how Aquileia, Emona, Sirmium and Viminacium looked in Roman times. It was assumed that the $3 \mathrm{D}$ reconstruction, as the main tool among other activities, would be the method to change the public's preconception that archaeology in an elitist and boring subject, understood only by specifically knowledgeable people.

At the very beginning of the project the target groups were identified and divided into three categories:

- Already existing audiences: general public, young people, families, disabled people, cultural professionals like archaeologists, 
conservators, historians, photographers, 3D designers and communicators of culture;

- Associations of professionals (connected to the project), government bodies at both a national and local level and international organisations;

- Non-audience: most important target group with the aim to be transformed into audience.

Additionally, the intention of the ARCHEST project was to support the archaeological sector and creative sectors related to archaeology to act at an international level and to advance the knowledge of common Roman history through a relationship with the most important archaeological sites so that visitors can experience a unique approach and modern technology that will lead potential visitors to become actual visitors and change the view of archaeology as a science to complicated for the general public to understand.

The first activity of the project was the photographic reportage, realised in each of the 5 sites involved (Aquileia, Ljubljana / Emona, Śćitarjevo
/ Andautonia, Sremska Mitrovica / Sirmium and Stari Kostolac ( Viminacium). From that action, fifty pictures were selected and used for the calendar, the Joint Historic Research on the Roman Road Aquileia-Emona-Viminacium, conducted by a multidisciplinary team led by one archaeologist from each of the countries that participated in the project, and the web site. The aim of this activity was to create a photo story with a unique design and approach capable of telling the story of the five sites in an emotional and evocative style. All the shots were made available to the partners with unlimited rights of use over time. This task was assigned to a professional photographer, with years of proven experience in the communication, promotion and enhancement of archaeological and cultural heritage. The photo campaign was realised in April of 2016 by the lead partner, given that in spring there is better light and shadows than in the other seasons of the year. During the project, photo exhibitions were organised along the route from Aquileia to Viminacium and visits to archaeolog-

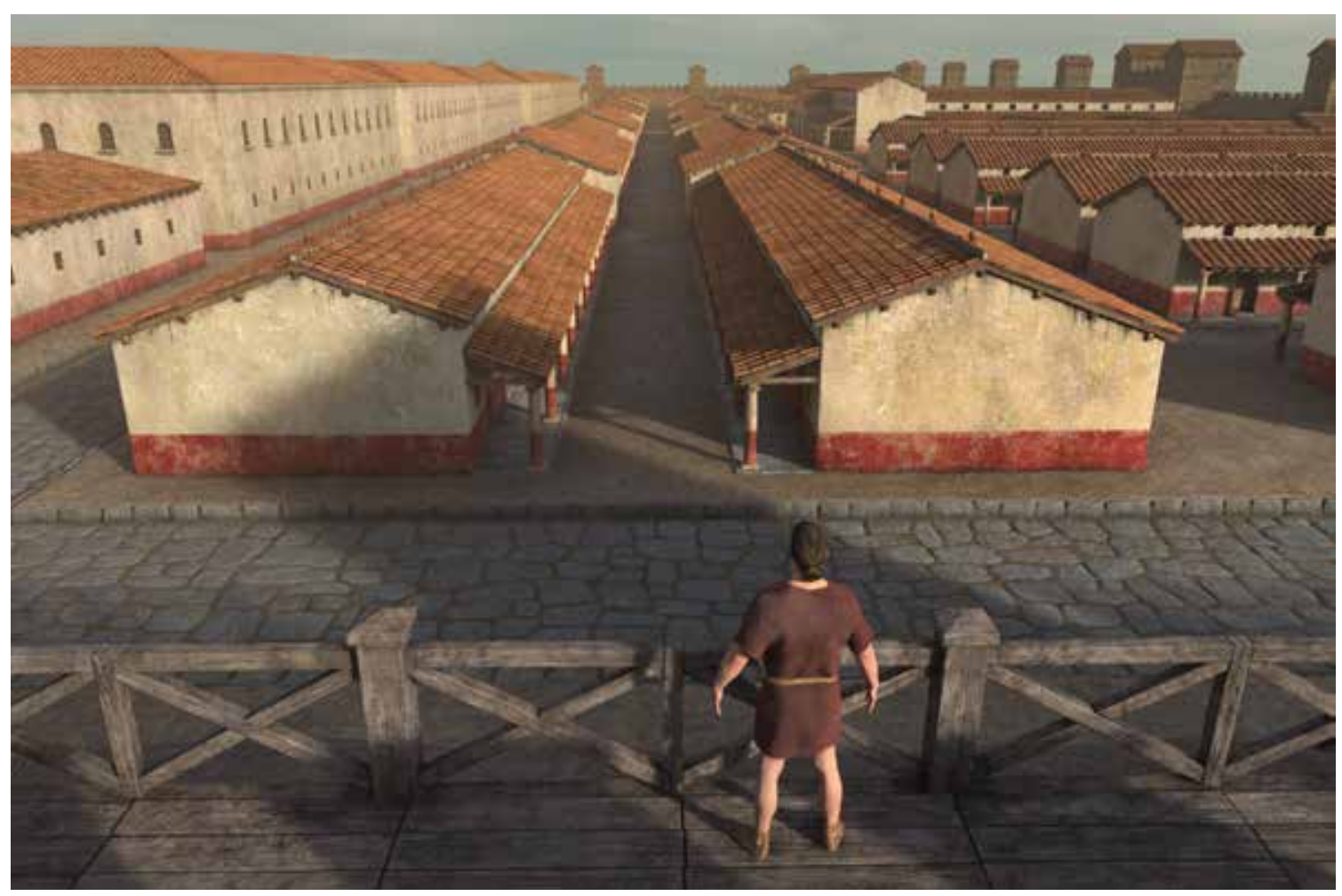

Fig. 6 Viminacium castrum reconstructed in 3D, legionary baracks. 
ical sites covered by 3D reconstruction in accordance with the audience development strategy.

In addition to the experts from the institutions, the project involved a large number of researchers and experts on specific issues related to the project. The general public were also involved by actively participating in the project through their acquaintance with the cultural heritage of this part of Europe. At the same time, the visualisation results were used to promote the ARCHEST project during various planned and unplanned events. Fairs were planned - the first one was the Tourism fair in Belgrade in late February 2017, and then one unplanned but excellent opportunity was the celebration of the 70th anniversary of the Archaeological Institute, in June 2017. It was used to present the first results of the 3D visualisation of the archaeological sites and the presentation of the ARCHEST project to a wider audience in front of the Serbian Academy of Sciences and Arts (SANU), in the most visited part of the heart of old Belgrade, Knez Mihailova street.
Shortly before this big celebration, in May 2017, ARCHEOBUS was organised, an educational tour for journalists and archaeologists along the Aquileia - Emona - Andautonia - Sirmium Viminacium route. Each partner sent five participants, archaeologists and journalists working for tourist and archaeological journals. It was an ideal opportunity for them to meet with colleagues from other countries (especially for the archaeologists) and to discuss the archaeology and tourist potential of the sites involved in the project. The six-day journey began in Aquileia, from where the participants travelled to Ljubljana / Emona, Šćitarjevo / Andautonia, Sremska Mitrovica / Sirmium and Kostolac and Viminacium. After the visit to Kostolac, the bus returned to Aquileia leaving the participants in their cities. In this way, the participants had more information and were able to easily present sites in order to attract visitors. The final goal, the growth of cultural tourism at the five sites, is expected in the next months after the very positive articles that appeared in several daily and

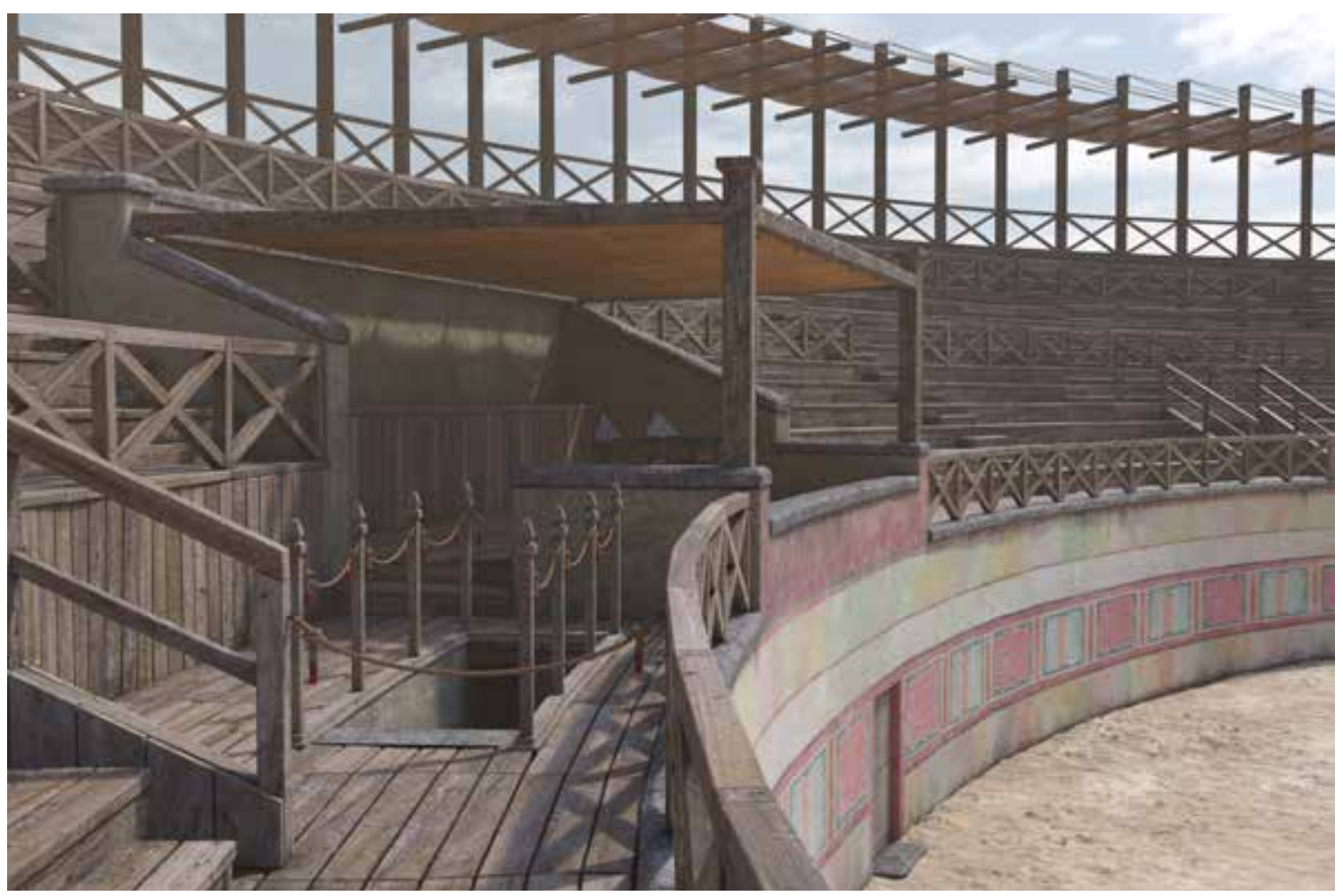

Fig. 7 Viminacium amphitheatre reconstructed in 3D. 


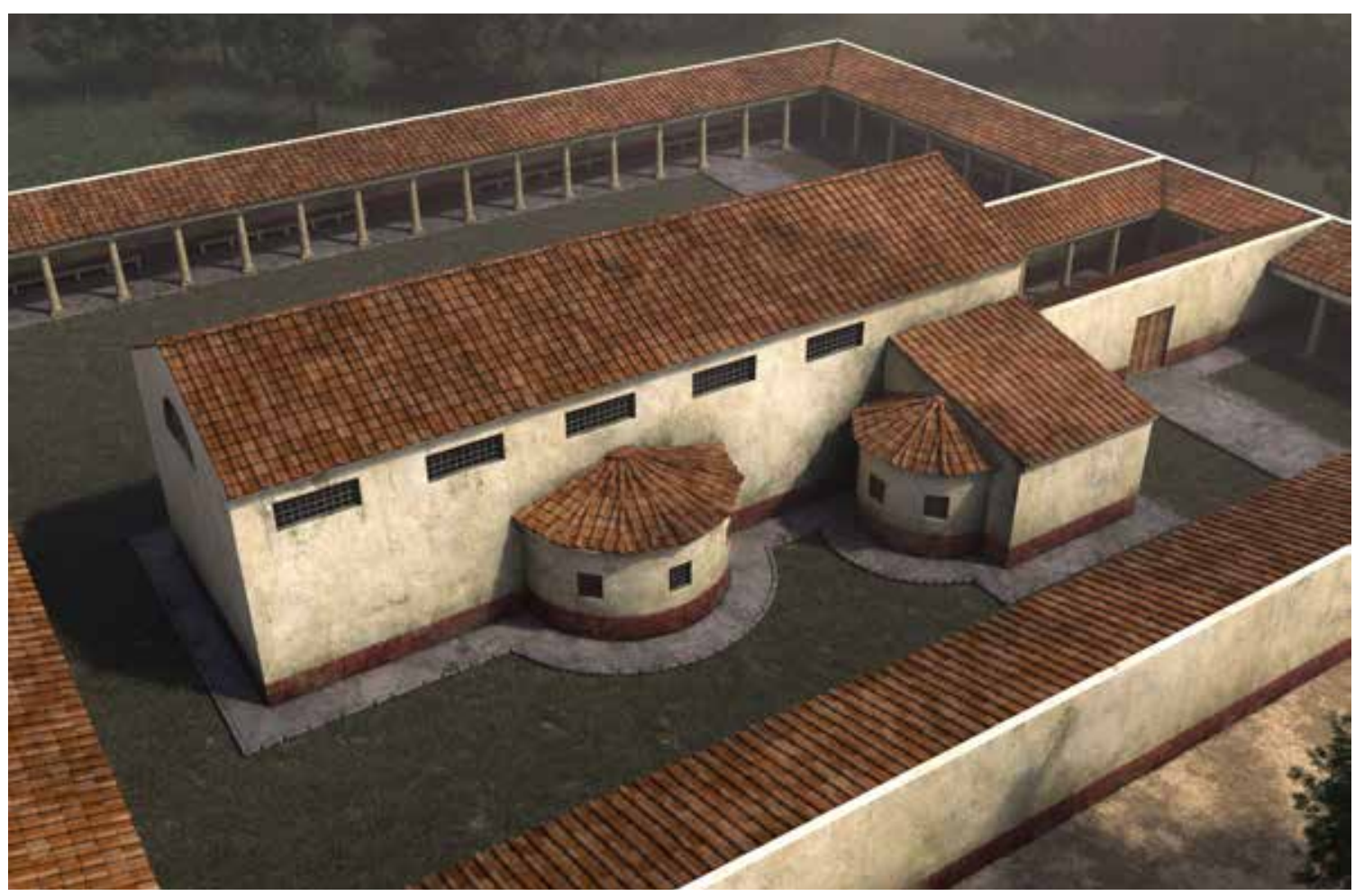

Fig. 8 Viminacium city baths (thermae) reconstructed in 3D.

weekly newspapers and their online editions, and as short reportages on state TV channels.

One of the tasks of the project was the development of guided tours for audience development. The partners in the project were fully aware that archaeology has always been considered little bit difficult, boring and not easily accessible to a wide audience. The probable reason is because archaeologists and conservators often use technical terms with many rare words, Latin words and other uncommon words. This also happens in the communication and dissemination of culture e.g. the terminology used in museums for captions. So, the archaeologists together with the communication / audience development managers involved in ARCHEST decided to try to make archaeology more accessible to a wider audience. In order to attract new audiences, maintain existing audience and change the attitude that the general public has towards archaeology, guided tours were organised by the partners in their own territories. The main challenge was to transform the non audience (resistors and rejecters) into a new audience.
The methodological tools were jointly developed by the partners and adapted according to specific contexts. Multidisciplinary teams composed of archaeologists, communication experts and guides were established in order to provide a holistic approach. Specific attention was paid to young people (children, students), to disabled people (e.g. blind people, mentally ill people) and to other disadvantaged groups. Tourist guides too often work using a standard style of language, but with ARCHEST we tried to adapt the message and the experience according to the target group involved by selecting the guides on the basis of the offer provided. The guides used modern technologies such as tablets onto which the $3 \mathrm{D}$ reconstructions had been uploaded. This allowed the audience to understand how the sites looked in Roman times and to have different emotions and experiences while visiting an archaeological site. 


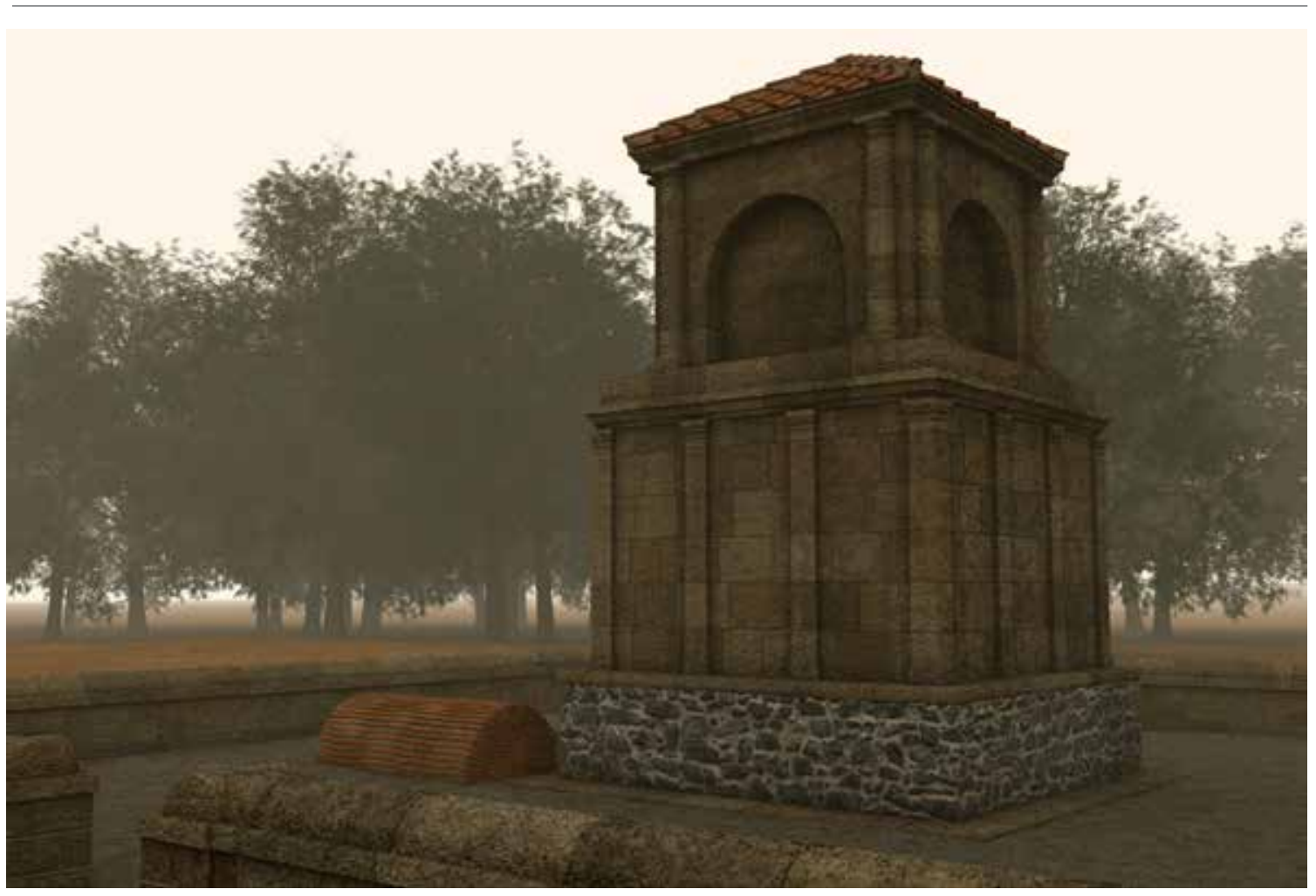

Fig. 9 Viminacium, $3^{\text {rd }}$ century mausoleum complex at the east part of the cemetery reconstructed in 3D.

\section{CONCLUSION}

The rebuilding of Viminacium in 3D and its use in presentations, guided tours and public events has already proved to be of enormous value.

The specific intentions of ARCHEST and the 3D modelling were to promote knowledge and the use of information and communication technologies applied to cultural heritage; to instruct those who make decisions and have a political impact on the importance of information and communication technologies for the enrichment of cultural heritage; to promote the internationalisation of workers in culture who are active in archaeology (archaeologists, photographers, 3D designers, graphic designers, promoters of science); to promote visitor education by paying particular attention to young people and people with disabilities; to strengthen a network of archaeological sites linking Italy with the Black Sea through Slovenia, Croatia, Serbia and Romania, and, very importantly, to promote knowledge of archaeologi- cal sites that are involved in a tourism project. In that sense, it was extremely important to present the project through 3D reconstructions and virtual reality, first during the celebration of the 70th anniversary of the Institute of Archaeology, then at the Tourism Fair in Novi Sad where the presentation was accompanied by a dramatic musical performance, and finally at the Festival of Science in Belgrade where the presentation of Project Viminacium was the most visited.

The mutual activities of the partners included promotions at national fairs. For that purpose each partner had access to all the materials, including the 3D models, in order to promote the results at both national and international fairs. Fondazione Aquileia distributed them in the Borsa Mediterranea del Turismo Archeologico, held in Paestum from $26^{\text {th }}$ to 29 th of October 2017. The Institute of Archaeology in Belgrade participated with a stand at the International Fair of Tourism, held in Belgrade in February 2017, which proved to be a great opportunity to promote the ARCHEST proj- 
ect's objectives and results by distributing flyers and merchandising material and informing visitors of the financed action's progress.

Also, the so-called archaeological days were organised with a series of lectures and educational and pedagogical workshops for pupils of higher classes of elementary and secondary schools, with the aim of bringing them closer to archaeology and history in an interesting way. Intensive work with journalists and the realisation of ARCHEOBUS resulted in real successes considering the publicity achieved and the ARCHEO OPEN DAYS in Sirmium, in August 2017 and in Viminacium, in December 2017.

After the finalisation of the work on the 3D reconstruction of the amphitheatre, legionary fortress and mausoleum from the eastern cemetery with developers and the static rendering and 3D video for tablets, we achieved $3 \mathrm{D}$ reconstructions based on the scientific results which allow us to help people understand and imagine how these sites looked 2,000 years ago.

We organised guided tours for different target groups (children, disabled people, an educational tour for journalists and archaeologist, and open days with schools and professionals) to involve new audiences, and also several workshops with high school students.

However, the greatest achievement is that, for the first time, the $3 \mathrm{D}$ reconstruction of four sites was made based on the results of scientific research obtained using cutting edge methods, excavations and geophysical surveys. Ultimately, the results have a huge appeal to ordinary audiences and support a better understanding and acceptance of Roman civilization through clear images which, at the same time, do not contradict the scientific concept but, rather, aim to support it.

\section{$* * *$}

Arheologija i prirodne nauke (Archaeology and Science) is an Open Access Journal. All articles can be downloaded free of charge and used in accordance with the licence Creative Commons
- Attribution-NonCommercial-NoDerivs 3.0 Serbia (https://creativecommons.org/licenses/bync-nd/3.0/rs/.

Časopis Arheologija i prirodne nauke je dostupan u režimu otvorenog pristupa. Članci objavljeni u časopisu mogu se besplatno preuzeti sa sajta i koristiti u skladu sa licencom Creative Commons - Autorstvo-Nekomercijalno-Bez prerada 3.0 Srbija (https://creativecommons.org/licenses/by$\mathrm{nc}-\mathrm{nd} / 3.0 / \mathrm{rs} /$.

\section{BIBLIOGRAPHY}

\section{Golubović, S. and Mrđić, N., 2013}

T-PAS - Project on tourist promotion of the archaeological sites along the route Aquileia, Emona, Viminacium, Arheologija i prirodne nauke 8 (2012), 101-112.

\section{Popović, V., 1993}

Sirmium - Grad careva i mučenika, in: Rimski gradovi i palate u Srbiji, ed. D. Srejović, Beograd.

Tiussi, C., ed. 2013

T-Pas, Tourist Promotion of the Archaeological Sites along the Roman Route Aquileia-Emona-Viminacium, ed. Cristiano Tiussi, Udine 2013, 65.

\section{REZIME RAĐANJE PROŠLOSTI - PODIZANJE VIMINACIJUMA U 3D I PREZENTACIJA KULTURNOG NASLEĐA}

\section{KLJUČNE REČI: 3D REKONSTRUKCIJE, VIR- TUELNA REALNOST, VIMINACIUM, ARCHEST}

Vizualizacija prošlosti je sigurno najsloženiji zadatak arheologije. Jedna je od najvažnijih naučnih zapovesti je da nešto nevidljivo, maglovito i tajanstveno, osvetli i učini vidljivim i bliskim. Arheolog proučava i istražuje drevne ostatke temeljno i sistematično kako bi mogao da razume i protumači 
mesta i događaje od pre nekoliko hiljada godina, ali ljudi koji posećuju arheološke lokalitete i muzeje nisu naučnici i nisu obrazovani da razumeju te ostatke. Otpatci ili smeće za neke, neprocenjivi su izvori saznanja za druge, a premošćivanje nauke i turizma ili arheologa i posetioca javlja se kao ozbiljan problem. Na imaginaciju posetilaca često utiču holivudski filmovi ili sopstvene bajkovite zamisli koje nisu zasnovane na dugotrajnim naučnim istraživanjima, tako da ustvari imaju prilično iskrivljenu sliku. Projekat ARCHEST je baš zbog toga imao za cilj ispravljanje, ali i poboljšanje prezentacije arheoloških lokaliteta i privlačenje novih posetilaca korišćenjem savremene tehnologije.

Da bi se "obnovio" grad razrušen pre 16 vekova bilo je neophodno koristiti profesionalni pristup, odnosno naučna saznanja stečena nakon decenija istraživanja u kombinaciji sa elementima naučne imaginacije koja bi dovela do rezultata prihvatljivog i razumljivog prosečnom posetiocu.

Viminacijuma je bio jedan od prvih projekata koji je uveo geofizička istraživanja u. Od 2002. godine za sistematsko istraživanje legijskog utvrđenja, gradskih i prigradskih primenjene su višestruke metode kako bi se dobila jasna slika arheoloških ostataka. Prilikom istraživanja Viminacijuma korišćeni su georadar, protonski magnetometar, merena elektro-otpornost tla, avio i satelitski snimci, a uvedeni su istovremeno sa razvojem GIS-a i arheološke baze podataka. Ukupna površina obuhvaćena multidisciplinarnim istraživanjem prelazi 600 hektara, od čega je 150 hektara temeljito skenirano i detaljno razrađenim metodama istraživanja.

Ovo je bila čvrsta osnova za stvaranje modela grada koji je kombinovao rezultate dugoročnih istraživanja gradova i tvrđava i, nažalost, samo delimična iskopavanja. Pošto ostanak Viminacijuma više nije vidljiv na površini, ovo je bilo važno za razvoj turizma i budućeg arheološkog parka. Vizuelizacija arheoloških ostataka i njihova prezentacija javnosti postala je glavni projekat koji je konačno rezultirao brzim razvojem.

Nakon završetka rada na 3D rekonstrukciji amfiteatra, legijskog utvrđenja, mauzoleja i gradskih termi sa programerima i statičkim renderingom, sa 3D video zapisima za tablete, doščo smo do $3 \mathrm{D}$ rekonstrukcija zasnovanih na naučnim rezultatima kako bi ljudi razumeli i zamislili kako su ove građevine izgledale pre 2000 godina.

Projekat ARCHEST je uspeo da kroz izradu 3D rekonstrukcija i uz uvođenje tehnologija proširene stvarnosti (augmented reality) koje posetiocima mogu da dočaraju izgled naselja u antičko vreme, predstavi četiri izuzetno važna arheološka nalazišta iz rimskog perioda (Akvileja, Emona, Sirmijum i Viminacijum).

Svrha projekta „ARCHEST-a” je da podrži arheološki sektor i kreativne sektore povezane sa arheologijom da deluju na lokalnom i međunarodnom nivou i unaprede poznavanje zajedničke rimske istorije kroz upoznavanje sa najvažnijim arheološkim nalazištima. Posetioca je potrebno privući jedinstvenim pristupom i savremenom tehnologijom čime će potencijalno postati učesnici u rekonstruisanoj stvarnosti i promeniti pristup arheologiji kao nečemu što je dosadno ili previše „elitističko“.

Najvećim dostignućem projekta smatra se to što su, po prvi put, 3D rekonstrukcije nastale analizom savremenih geofizičkih i arheoloških istraživanja. Krajnji rezultat je ispao toliko privlačan za prosećnu publiku da podstiče mnogo bolje razumevanje i prihvatanje znanja o rimskoj civilizaciji putem "živih" slika, a istovremeno nije u suprotnosti sa naučnim konceptom, već ga podržava. 